\title{
Solar Energy in Cuba: Current Situation and Future Development
}

\author{
Jorge Morales Pedraza
}

\author{
Independent Researcher and Senior Consultant in Morales Project Consulting, Vienna, Austria
}

\begin{abstract}
Cuba, a small island in the Caribbean Sea with a total land area of $109.884 \mathrm{~km}^{2}$ and a population of around 11.423 million, has no significant proved oil, gas and coal reserves. Also use, in a very limited manner, some of the four main renewable energy sources available in the country for electricity production, generating just $50,1 \mathrm{GW} / \mathrm{h}$ or $4,04 \%$ of the total electricity consumed in $2015(20.288 \mathrm{GW} / \mathrm{h})$. In 2016 , electricity consumption fell to $15.182 \mathrm{GW} / \mathrm{h}$; this means a reduction of $25 \%$ in comparison to 2015 . In 2016, the participation of renewable energy sources in the energy mix of the country reached $4,65 \%$.

The different renewable energy sources available in the country are hydropower, wind power, solar photovoltaic, and bioenergy. In 2015, out of Cuba's total $566 \mathrm{MW}$ of renewable energy capacity installed, $83 \%$ of the total was in the bioenergy sector. In 2016, the renewable energy capacity installed in the country reached $642 \mathrm{MW}$.

According to the decision adopted by the Cuban government, the participation of renewable energy sources in the energy mix of the country should reach $24 \%$ in 2030, an increase of almost $20 \%$ compared to the level reported in 2016. Among the different renewable energy sources available in the country, solar energy is one of the main contributors to the national energy system, and also one of the leading supplier of energy to independent users all over the country.
\end{abstract}

Keywords: Energy policy, Renewable energy sources, Solar photovoltaic, Renewable thermal, Hydropower, Solar energy, Wind energy, Electricity generation.

\section{THE CUBAN ENERGY SECTOR}

According to Morales Pedraza (2018), "it is an undisputed reality that the energy production, particularly the electricity generation and their sustained growth, constitute an indispensable element for the economic and social progress of any country. Without a doubt, energy is the motive force of the civilization, and decides, in a high degree, the level of economic and social development that a country could reach".

Cuba, the largest island in the Caribbean Sea with a total land area of $109.884 \mathrm{~km}^{2}$ and a population of around 11.423 million, according to the OLADE 2018 report, has no significant proved oil, natural gas, and coal $^{1}$ reserves (see Tables 1, 2 and 3 ), and use, in a very limited manner, some of the four main renewable energy sources available in the country.

In 2019, according to sources from the Ministry of Energy and Mines (MEM), Cuba has a total installed capacity of $5.881 \mathrm{MW}$ and $100 \%$ power coverage using different energy sources. The total installed

*Address correspondence to this author at the Independent Researcher and Senior Consultant in Morales Project Consulting, Vienna, Austria;

Tel: +43 676742 8225; E-mail: jmorales47@hotmail.com

${ }^{1}$ According to EIA database (2018) and government sources, the country has no proved coal reserves. renewable power generation capacity in Cuba, in 2016, reached $642 \mathrm{MW}$ representing $10 \%$ of the full power capacity installed (see Figure 1). By type of renewable energy source, the installed power capacity is the following:

- Renewable thermal: $529 \mathrm{MW}$ or $8,2 \%$ of the total;

- Hydropower: $66 \mathrm{MW}$ or $1 \%$ of the total;

- Solar energy: $37 \mathrm{MW}$ or $0,6 \%$ of the total;

- Wind energy: $10 \mathrm{MW}$ or 0,25 of the total (OLADE, 2018).

The total electricity generated in 2016 reached 20.334 MWh. The total energy produced in 2016 by renewable energy sources reached $811 \mathrm{GWh}$ or almost $4 \%$ of the total. The electricity generated by the different energy sources in that year was the following:

- Renewable thermal: $686 \mathrm{GWh}$ or $3,4 \%$ of the total;

- Hydropower $64 \mathrm{GWh}$ or $0,3 \%$ of the total;

- $\quad$ Solar energy: $39 \mathrm{GWh}$ or $0,2 \%$ of the total;

- Wind energy: $21 \mathrm{GWh}$ or $0,1 \%$ of the total.

In 2016, out of Cuba's total $642 \mathrm{MW}$ of renewable energy capacity installed, $0,2 \%$ of the total was in the solar energy sector. The government desires that the participation of renewable energy sources in the energy 


\section{Renewable Capacity Installed During the Period 2010-2016 (MW)}

$$
\begin{aligned}
& -618=620=594-555-594-566=642 \\
& \begin{array}{lllllll}
2010 & 2011 & 2012 & 2013 & 2014 & 2015 & 2016
\end{array} \\
& \text { - - Renewable capacity installed during the period 2010-2016 (MW) }
\end{aligned}
$$

Source: IRENA and OLADE (2018) for the year 2016.

Figure 1: Evolution of the total renewable energy sources capacity installed in Cuba during the period 2010-2016.

mix of the country reaches $24 \%$ in 2030 . To increase the current percentage in the use of renewable energy source in 2019, an investment program of 275 million pesos for the assembly of solar parks, wind farms, and bioelectric power plants have been approved by the government, according to the Ministry of Energy and Mines.

Table 1: Proved Oil Reserves in Latin America and the Caribbean region in 2017

\begin{tabular}{|c|c|}
\hline Countries & Proved Oil Reserves (billion barrels) \\
\hline \hline Argentina & 2,2 \\
\hline Bolivia & 0,2 \\
\hline Brazil & 13 \\
\hline Chile & 0,2 \\
\hline Colombia & 2,0 \\
\hline Costa Rica & 0,0 \\
\hline Cuba & 0,1 \\
\hline Ecuador & 8,3 \\
\hline Jamaica & 0,0 \\
\hline Mexico & 7,3 \\
\hline Paraguay & 0,0 \\
\hline Trinidad \& Tobago & 0,2 \\
\hline Uruguay & 0,0 \\
\hline Venezuela & 301 \\
\hline
\end{tabular}

Source: US Energy Information Administration (2018).

According to Table 1, Cuba has very limited oil reserves and occupy the position number 10 considering the level of oil reserves of other Latin American and the Caribbean countries. The country imports around $55 \%$ of its oil needs and produce around $45 \%$.
Table 2: Proved Natural Gas Reserves in Latin America and the Caribbean region in 2017

\begin{tabular}{|c|c|}
\hline Countries & $\begin{array}{c}\text { Proved natural gas reserves } \\
\text { (trillion cubic feet) }\end{array}$ \\
\hline \hline Argentina & 11 \\
\hline Bolivia & 10 \\
\hline Brazil & 15 \\
\hline Chile & 3,5 \\
\hline Colombia & 4,4 \\
\hline Cuba & 2,5 \\
\hline Mexico & 12 \\
\hline Peru & 14 \\
\hline Trinidad \& Tobago & 11 \\
\hline Venezuela & 201 \\
\hline
\end{tabular}

Source: US Energy Information Administration (2018)

According to the information included in Table 2, Cuba has a very low natural gas reserves in comparison with other countries within the region, and this situation is not expected to change during the coming years.

Based on the information included in Table 3, Cuba has no coal reserves and, for this reason, the government does not foresee the use of this type of energy source for electricity generation during the coming decades, in addition to the negative impact on the environment and the population as a result of the use of coal with this specific purpose.

The energy sector in Cuba has undergone a series of changes, which has allowed the distribution of electricity to towns and villages throughout the country and to reach all of them without exception. These changes have been already included in the documents entitled "Cuban Electricity Conservation Program (PAEC)" and "Energy Conservation Program of the 
Table 3: Proved Coal Reserves in Latin America and the Caribbean region in 2017

\begin{tabular}{|c|c|}
\hline Countries & Proved reserves (million short tons) \\
\hline \hline Argentina & 551 \\
\hline Bolivia & 1,1 \\
\hline Brazil & 7.271 \\
\hline Chile & 1.302 \\
\hline Colombia & 5.380 \\
\hline Costa Rica & 0,0 \\
\hline Cuba & 0,0 \\
\hline Ecuador & 26 \\
\hline Jamaica & 0,0 \\
\hline Mexico & 1.335 \\
\hline Paraguay & 0,0 \\
\hline Peru & 112 \\
\hline Uruguay & 0,0 \\
\hline Venezuela & 806 \\
\hline
\end{tabular}

Source: US Energy Information Administration (2018)

Ministry of Education (PAEME)," both approved by the government. In addition to the programs mentioned above, in 2016, the Cuban government adopted the socalled "Energy Revolution Program," which has changed the way the country transforms and use the diverse sources of energy available in the country (Suárez et al., 2012).

Unfortunately, Cuba has not yet overcome completely the economic crisis of the 1990s, which affected significantly all economic sectors, particularly the energy sector, due to several external and internal factors. The main external factors are, among others, the following:

- The persistence of the US economic embargo against Cuba in force since the 1960s;

- Lack of foreign investors ready to support the financing of relevant projects in the primary economic sectors;

- The downfall of the Soviet Union and other socialist countries in the 1990s;

- The catastrophic effects of several hurricanes that cross the country in the last years.

The main internal factors are, among others, the following:
- $\quad$ Low productivity;

- Low application of science, new technology, and innovation;

- Technological backwardness in several economic sectors;

- Unnecessary restrictions in bringing foreign investors to support the implementation of key projects in the primary economic areas, and complex procedures to consider and approve new projects by the government;

- $\quad$ Lack of adequate preparation of the officials in charge of the negotiation of new projects submitted by foreign investors;

- Low correspondence between the level of activities and the financial, material, and human resources consumed;

- $\quad$ Low salaries;

- Insufficient energy conservation measures;

- Low production and export level of goods and elevated level of imported basic food;

- Poor results of the political and economic reforms adopted by the government (Morales Pedraza, 2018).

For 2030, the primary goal of the government in the power sector is to generate $24 \%$ of all electricity produced within the country using different renewable energy sources. To achieve this goal, Cuba would need, only in the energy sector, capital investments of US $\$ 3,5$ billion to increase the participation of renewable energy sources in the energy mix of the country in the future and to install other $2 \mathrm{GW}$ generation capacity during the coming years.

According to the minister of Energy and Mines, in 2019, the percentage of the electrification of the whole country reached $100 \%$, the highest in the region, throughout the use of conventional energy, particularly oil and natural gas, and several renewable energy sources such as solar energy, wind energy, hydropower, and bioenergy. In isolated or difficult to access areas, the government used solar photovoltaic panels installed in private houses and social facilities to provide them with electricity. 
Based on official statistics provided by the minister of Energy and Mines in a visit carried out in March 2017 in Germany, Cuba has:

- $\quad 22$ solar photovoltaic parks actually in operation with a total capacity of $37 \mathrm{MW}$;

- $\quad 9.476$ solar panels installed;

- $\quad 9.343$ windmills;

- $\quad 6.447$ solar heaters;

- 827 biogas plants;

- $\quad 169$ hydroelectric power plants;

- $\quad$ Four wind farms with 20 wind turbines;

- $\quad 57$ sugar mills;

- 608 stoves for wood biomass pellet production;

- $\quad 57$ turbo generators;

- $\quad 67$ boilers in several sugar mills.

In addition to the above information, and according to Cuban sources, the country has built, until the end of 2017, a total of 34 solar photovoltaic parks synchronized to the national electrical system, with an installed capacity of $90 \mathrm{MW}$. This is a remarkable achievement because, the use of solar photovoltaic in Cuba began in 2011 with the installation of about 9.000 small systems located in remote places where the national electricity network did not exist, distributed in medical clinics, rural schools, private homes, and cultural facilities. The capacity installed was $3,46 \mathrm{MWp}$. In 2012, began de program for the construction of solar photovoltaic parks but to be connected to the national electrical grid. The first solar photovoltaic park connected to the national electrical grid was built in 2012 in Cantarrana in the Cienfuegos province.

Many experts see as a good sign the government's decision to give priority to the use of all available renewable energy sources within the country for electricity generation, as set up in an extensive program launched in April 2011. This program aims to modernize the economy and to enhance its efficiency, and includes reactivating windmill factories, revitalizing the hydroelectric turbine industry, and the development of the solar panel production as much as possible, bearing in mind that these have been the best options in a rural electrification program implemented by the Cuban government over the past 10 years.
The Cuban government has recognized that it cannot move alone and at a faster pace (in the development of its energy sector) due, among other elements, to the country's substantial financial limitations. Cuba has no choice, under its current economic situation, but to turn to international investors to achieve its target of $24 \%$ of the total electricity to be generated by the country in 2030 using all available renewable energy sources.

\section{CUBAN ENERGY POLICY}

The preparation of a national energy policy in which priorities and preferences are identified should be one of the primary responsibilities of the national authorities responsible for the energy sector in Cuba. This energy policy should represent a compromise between expected energy shortages, environmental quality, energy cost, public attitudes, safety and security, available skills, as well as production and service capabilities. Relevant national authorities must take these elements into account during any future revision of the national energy policy already approved by the government (Morales Pedraza, 2018).

To implement the newly approved energy policy until 2030, Cuba is promoting foreign investments not only to increase the use of renewable energy sources for electricity generation but also to reduce the use of fossil fuel for the same purpose as well. However, the process set up by the government for the approval of new projects in the energy sector with the participation of foreign firms makes very complicated its consideration, approval, and implementation. For this reason, more reforms are necessary to speed up the review and approval of new investment projects within the energy sector in the future. A significant increase in energy efficiency and conservation is another of the goals to be achieved by the government by 2030 , with the aim of reducing the participation of oil in the energy mix of the country in the future.

\subsection{Problems with the Electrical Distribution Grid}

Despite all saving energy measures adopted by the government in recent years, the existence of an ancient and inefficient electrical distribution grid, provoke that the distribution and transmission losses in Cuba are higher than international standards $(17,6 \%$ of the total electricity produced in 2014). The government aims to reduce the current level of electricity loss to $14 \%$ or less at the end of the present decade. 
According to Cuban experts, one of the best ways to give energy security is to move from centralized to a distributed energy system ${ }^{2}$ (now between 40 and $42 \%$ of the energy produced in Cuba is by this system), which partly has been developed as a response to high exposure to damages caused by extreme weather conditions and natural disasters, including hurricanes. The decentralization of electricity production has increased the reliability of supply and improved efficiency when new smaller-scale power plants have replaced older technology (Morales Pedraza, 2018).

The strategy adopted by the government also promotes the diversification of energy sources while making it easier to change to the use of renewable energy sources in the future. In 2006, and because of the measures adopted by the government in the energy sector, Cuba installed 1.854 diesel and fuel oil microelectrical power plants across the country, representing over $3.000 \mathrm{MW}$ of decentralized power in 110 municipalities ${ }^{3}$.

In addition to the installation of new power plants, the government also installed over 4.000 emergency back-up systems in critical areas like hospitals, food production centers, schools, and other sites key to Cuba's economy. A total of $500 \mathrm{MW}$ of emergency back-up power was installed for electricity generation.

\section{ELECTRICITY GENERATION AND CONSUM- PTION}

According to the US Energy Information Administration, in 2016, the generation and consumption of electricity in a group of Latin America and the Caribbean countries is shown in Table 4.

According to the information included in Table 4, Cuba occupies, in 2016 , the 11 th position respect to the level of electricity production and $9^{\text {th }}$ in the level of electricity consumption within the region. The electricity consumption in Cuba, in 2016, reached 16 billion kW/h, the same level reported by the Dominican Republic.

\footnotetext{
2 Currently, Cuba has a generating capacity of $2.418 \mathrm{MW}$ based on distributed generation. A total of $1.280 \mathrm{MW}$ corresponds to diesel generators and the rest are fuel oil motors (540 MW), CHP (529 MW) and renewable technologies (69 MW) (Suárez et al., 2012). This means that between 40 and $42 \%$ of the generation capacity is in distributed systems: a very significant shift away from a centralized power system that Cuba has in the past.

${ }^{3}$ Before the end of 2019, and according to public sources, the government hopes to start the operation of the most modern thermoelectric power plant using diesel as fuel in the Cienfuegos province. The new plant will be composed by 40 generators and will provide $60 \%$ of the province energy needs.
}

Table 4: Electricity Generation in a group of Latin America and the Caribbean countries in 2016

\begin{tabular}{|c|c|c|}
\hline Countries & $\begin{array}{l}\text { Power generation } \\
\text { (billion kWh) }\end{array}$ & $\begin{array}{l}\text { Power consumption } \\
\text { (billion kWh) }\end{array}$ \\
\hline Argentina & 132 & 121 \\
\hline Bolivia & 9,0 & 7,8 \\
\hline Brazil & 568 & 509 \\
\hline Chile & 76 & 73 \\
\hline Colombia & 75 & 68 \\
\hline Costa Rica & 11 & 9,8 \\
\hline Cuba & 19 & 16 \\
\hline Ecuador & 27 & 23 \\
\hline El Salvador & 5,8 & 5,9 \\
\hline Guatemala & 12 & 10 \\
\hline Guyana & 1,0 & 0,8 \\
\hline Haiti & 1,0 & 0,4 \\
\hline Honduras & 8,5 & 7,2 \\
\hline Jamaica & 4,0 & 2,8 \\
\hline Mexico & 303 & 259 \\
\hline Nicaragua & 4,5 & 3,6 \\
\hline Panama & 11 & 8,7 \\
\hline Paraguay & 63 & 11 \\
\hline Peru & 50 & 45 \\
\hline $\begin{array}{l}\text { Dominican } \\
\text { Republic }\end{array}$ & 18 & 16 \\
\hline Suriname & 2 & 1,7 \\
\hline Uruguay & 13 & 11 \\
\hline Venezuela & 109 & 72 \\
\hline
\end{tabular}

Source: US Energy Information Administration database 2019.

\section{THE CURRENT SITUATION OF THE RENEWABLE ENERGY SECTOR IN CUBA}

According to Moreno Figueredo, in 2017, the following types of renewable energy sources, technologies, and applications were available in Cuba:

\section{A. For electricity generation:}

- $\quad$ Wind power (four wind farms with a total capacity of $11 \mathrm{MW}$, and 9.343 small wind turbines);

- Solar photovoltaic ${ }^{4}$ (more than 9.000 solar panels isolated from the grid $^{5}$;

\footnotetext{
${ }^{4}$ Average solar radiation in Cuba is higher than $1.800 \mathrm{~kW} / \mathrm{m}^{2}$ per year This average is very good for the use of solar photovoltaic systems for electricity generation.

${ }^{5}$ There are in Cuba, according to government sources, a total of 9.476 solar panels used for electricity generation not connected to the national grid all over the country (Moreno Figueredo).
} 
- $\quad$ Small and mini hydropower (169 hydropower plants running throughout the country with a total installed capacity of $71,9 \mathrm{MW}$, of which 34 units are connected to the national grid, and 135 units give electricity to 8.486 homes and 416 economic and social facilities);

\section{B. For the reduction of electricity consumption,} gas, and other energy carriers:

- Co-generation of heat (steam) in the sugar industry;

- $\quad$ Solar thermal energy;

- $\quad$ Windmills for pumping water (9.343 units);

- $\quad$ Biogas for cooking food;

- $\quad$ Forest biomass for cooking food;

- $\quad$ Biofuels for transport.

Cuba intends to increase the participation of all available renewable energy sources in the electricity generation sector over the next eight years, with the aim of improving security and energy sovereignty. In the particular case of solar energy, the expansion in the use of this type of energy source should be carried out under the following conditions:

- The construction of solar photovoltaic parks should not use fertile land that can be used for agriculture purposes, particularly for the production of food;

- The capacity of the solar photovoltaic parks should take into account the consumption level of the potential consumers with the aim of reducing to the minimum losses by transmission, distribution, and transformation;

- The use of solar energy for electricity generation should improve the reliability of the electrical network, and should not be a destabilizing force of the grid;

- The solar photovoltaic systems used should be designed to withstand winds of more than 150 $\mathrm{km} / \mathrm{hour}$;

- The solar photovoltaic system should be constructed correctly, following international standards and the Cuban norms.
In 2016 , around $4 \%$ of the electricity generated throughout the country was produced using renewable energy sources; over the next eight years, this percentage should be $16,5 \%$, a little bit more than four times than the level reported today, according to government sources. To reach that goal, the participation of the different renewable energy sources in the energy mix of the country, in 2030 , should be, according to Ramada (2016), the following:

- $\quad$ Biomass: $14 \%$;

- Wind energy: $6 \%$;

- $\quad$ Solar photovoltaic: $3 \%$

- $\quad$ Hydropower: $1 \%$.

According to government sources, the potential of solar energy recognized throughout the country exceeds $2.000 \mathrm{MW}$, but the plan is to install only 700 MW by 2030 .

\section{SOLAR PHOTOVOLTAIC PARKS UNDER CONSTRUCTION AND IN OPERATION}

During the 2010s, the Cuban government began an intensive program for the construction of solar photovoltaic parks to increase the participation of solar energy in the energy mix of the country. In 2013, the first solar photovoltaic park in Cuba began operation in Cienfuegos, in the central south part of the island. As a result of the implementation of the program mentioned above, Cuba has already in operation 22 solar photovoltaic parks with a generating capacity of $37 \mathrm{MW}$ (see Figure 4), and by the end of the year 2017, seven additional solar photovoltaic parks of a plan of 32 parks with a total capacity of $89 \mathrm{MW}$ were completed. The seven parks have a full capacity of $11 \mathrm{MW}$ (see Figure 4). In 2018, the government plans to build 27 new solar photovoltaic parks with a full capacity of $95 \mathrm{MW}$ (see Figure 4). The Cuban government has plans for the construction of a total of 191 solar photovoltaic parks with a total installed capacity of $700 \mathrm{MW}$ by 2030 (Figueredo et al., 2017) with a total generation capacity of $1.050 \mathrm{GWh}$ per year. A total of 240 million tons of oil per year will be saved as a result of the operation of these solar photovoltaic parks.

After the adoption of the National Energy Sources Development Program, the Cuban government supported the installation of 2.364 solar photovoltaic systems on rural schools, making lights, computers, and educational television programs accessible to almost all students in the country. In addition to these 
actions, the government began, in 2017, the implementation of a national plan for the supply of solar photovoltaic panels to be installed in private houses for electricity generation. "A total of 9.476 solar photovoltaic systems have been installed with this specific purpose" (See Figures 2 and 3) (Morales Pedraza, 2018).

Solar photovoltaic technologies used in Cuba for electricity generation are planned for a 20-25-year's life cycle. The use of this technology ensures the electricity generation in the most efficient manner and takes advantage of the available solar potential throughout the territory. During the life cycle of a solar photovoltaic park, each MW installed should generate 38.750 $\mathrm{MW} / \mathrm{h}$. This represents a saving of more than US\$2,5 million only in fuel consumption and failing to emit 127.875 tons of $\mathrm{CO}_{2}$ into the atmosphere.
"According to estimates of Cuban specialists on the subject, in $100 \mathrm{~km}^{2}$ a total of $15.000 \mathrm{GW} / \mathrm{h}$ per year can be generated, which is somehow like the current electricity generation based on conventional fuels" (Morales Pedraza, 2018).

\subsection{Solar Investment in the Power Sector}

Until May 2017, Cuba has built 22 solar photovoltaic parks with a total capacity of 37 MW. The plan for 2018 is shown in Figure 4.

In 2015, the Cuban government approved an increase of $700 \mathrm{MW}$ in the current solar photovoltaic capacity to be installed in the country by 2030 . Out of this total, $350 \mathrm{MW}$ will be constructed by the Cuban government with its own resources, and foreign companies will build the remaining $350 \mathrm{MW}$. According to the standard of US\$2 million per MW that Cuba uses

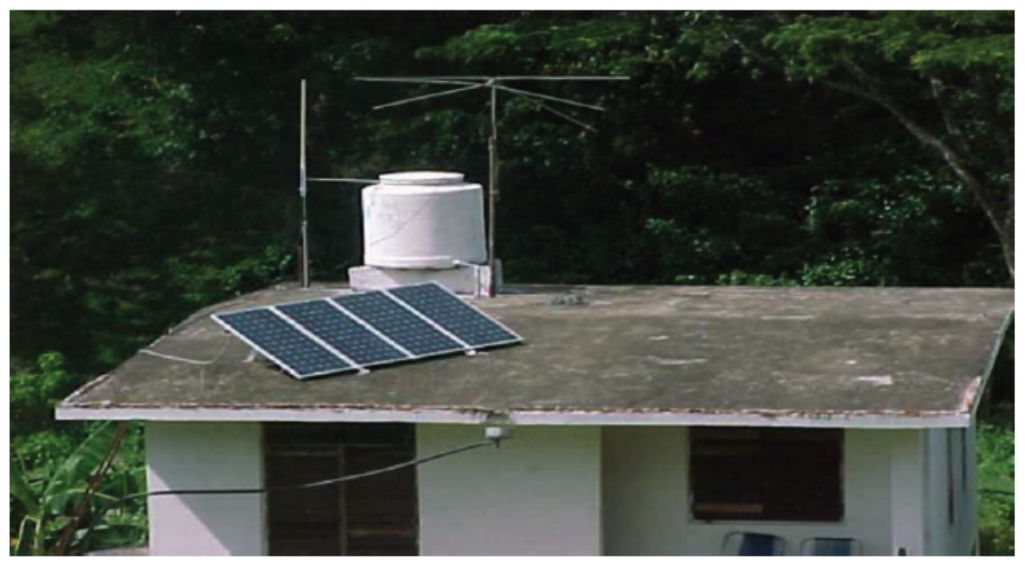

Source: Cuba Energía

Figure 2: Solar photovoltaic systems installed in a rural medical post.

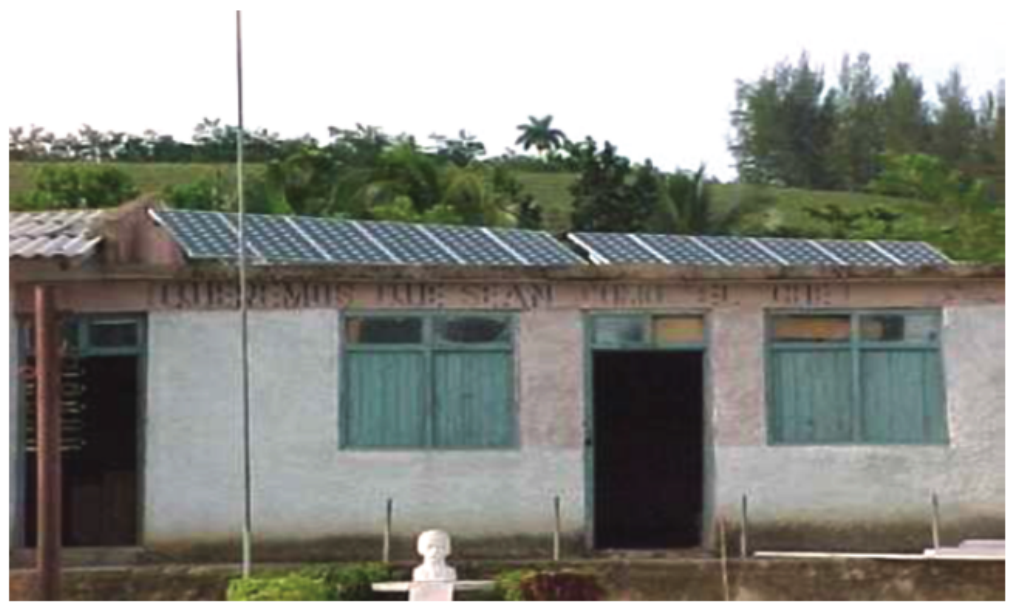

Source: Cuba Energía

Figure 3: Solar photovoltaic systems installed in a rural school. 


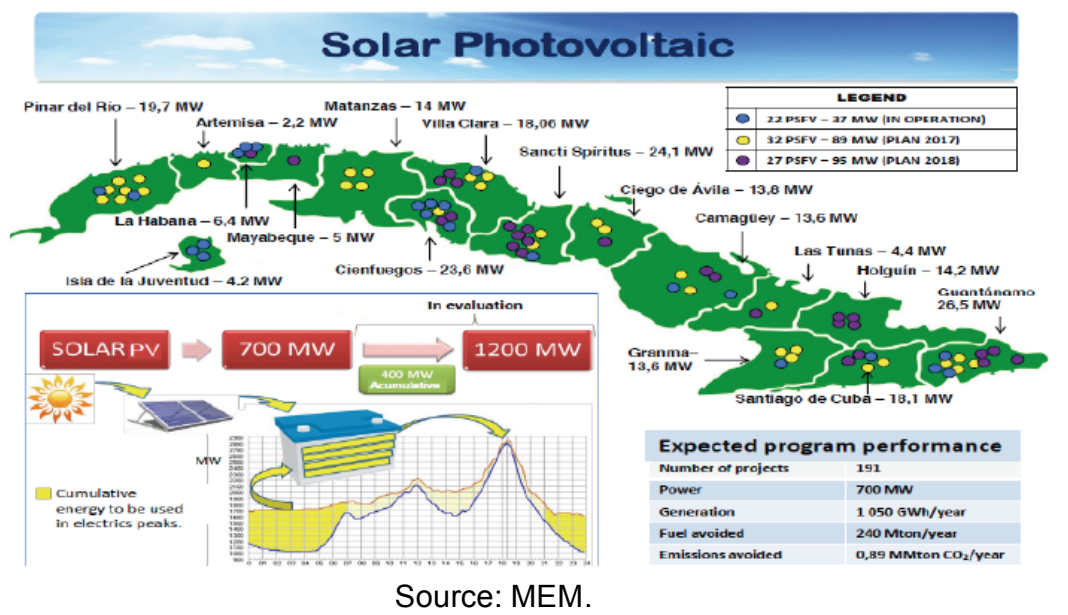

Figure 4: Solar photovoltaic parks to be constructed in 2018.

in its investment portfolio in the energy sector, the total cost of the projects under negotiation with foreign companies would be US\$700 million. The solar photovoltaic parks under consideration by the Cuban government are expected to generate around 1.000 $\mathrm{GW} / \mathrm{h}$ per year, avoiding the emission of 874.000 tons of $\mathrm{CO}_{2}$ (Morales Pedraza, 2018).

A total of 17 solar photovoltaic parks with a capacity of $100 \mathrm{MW}$ will be built by foreign companies in four provinces in the western part of the country (Pinar del Rio, Mayabeque, Artemisa and Matanzas). All these solar photovoltaic parks are to be built under the buildown-operate (BOO) type of contract. The state utility "Electrical National Union" (Unión Nacional Eléctrica, UNE) will be the sole buyer of the electricity generated by these parks, paying a fixed negotiated price during the next 25 years. Additional $184 \mathrm{MW}$ of capacity will also be constructed in 59 solar photovoltaic parks in a selected group of provinces in the central and eastern regions of the country ${ }^{6}$ (see Figure 4).

Credit from the Renewable Energy Agency will facilitate the lifting of four solar photovoltaic parks with a capacity of $10 \mathrm{MW}$ in the coming years. Another loan granted to the electronics industry will enable to build 16 new solar photovoltaic parks with a total capacity of 40 MW shortly (Figueredo et al., 2017).

\subsection{Solar Photovoltaic Parks under Construction or in Operation}

According to Morales Pedraza (2018), there are

\footnotetext{
${ }^{6}$ Three solar photovoltaic parks with a total capacity of $50 \mathrm{MW}$ will be constructed by UK-based "Hive Energy" in the Mariel Special Development Zone.
}

several solar photovoltaic parks under construction or in operation in Cuba. The location where these solar photovoltaic parks are under construction or in service are the following:

\subsubsection{Camagüey}

Camagüey began, in May 2016, the construction of its second solar photovoltaic park, designed to generate $1,2 \mathrm{MW} / \mathrm{h}$, has 4.800 solar panels and is located near the Integrated Water Technology Center (CITA), in the north of the city. The functioning of the solar photovoltaic park in the CITA area will decrease diesel consumption equivalent to over 1.200 tons in one year and avoids the emission of more than 1.500 tons of $\mathrm{CO}_{2}$.

Camagüey inaugurated, in 2017, its third solar photovoltaic park with a capacity to generate $5 \mathrm{MW} / \mathrm{h}$. By 2030, the province of Camagüey will be able to produce around $60 \mathrm{MW} / \mathrm{h}$, thanks to the construction of several solar photovoltaic parks, with a capacity between 5 and $10 \mathrm{MW} / \mathrm{h}$ each, most in the periphery of the capital city.

It is worth mentioning that more than 200 independent solar photovoltaic panels are already installed in the province today for electricity generation in schools, video, and computer rooms, as well as in isolated communities.

According to government sources, during the period 2018-2019 a solar photovoltaic park with a total capacity of $5 \mathrm{MW}$ will be completed in the province of Camagüey. The construction of the park will be divided into two phases. One MW of capacity will be constructed in the first phase, and the remaining $4 \mathrm{MW}$ 
of capacity will be available at the end of the second phase.

The total solar photovoltaic capacity already installed in the province reached 2,8 MW and included the solar photovoltaic park built in the municipality of Guáimaro two years ago. The installation of the solar photovoltaic park in Guáimaro saved in its first year of operation the consumption of more than 500 tons of oil.

\subsubsection{Cienfuegos}

Cuba's first solar photovoltaic park opened in 2013 in Cantarrana in the central province of Cienfuegos, $300 \mathrm{~km}$ east of Havana. It boasts 14.000 photovoltaic panels. In April 2013, the park began contributing to the island's energy grid (Rodriguez, 2013).

According to the Newsletter "FRE" 2016, in the province of Cienfuegos began, in March 2016, in very rocky terrain, the movement of land for the future construction of a new solar photovoltaic park called "EI Pino." The solar photovoltaic park, located in an area near the municipality of Rhodes, is erected at 6.540.000 Cuban pesos. The generating capacity of "EI Pino" is 2,2 MW, and has 3.520 foundations, 880 tables, and 8.800 solar panels. With the beginning of the electricity generation by this park in 2017, the total capacity of the province increased to $11,2 \mathrm{MW}$.

In 2018, in Yaguaramas, a Cienfuegos municipality of Abreus, a solar photovoltaic park with $5 \mathrm{MW}$ peak generation capacity, the largest in the country funded by the government of the People's Republic of China, started to generate electricity to the national grid $^{7}$. The park has 19.440 solar panels, 8.100 desks, and the construction cost was around 17 million Cuban pesos.

The existence of several free lands in Cienfuegos could allow the construction of several solar photovoltaic parks with a total capacity of $60 \mathrm{MW}$ by 2030.

\subsubsection{Pinar del Rio}

In the province of Pinar del Rio, in the western part of the island, the construction of the first solar photovoltaic park began in January 2015 (See Figure 5). The park with a capacity of $3 \mathrm{MW}$ will contribute to a circuit that feeds the wells that serve all the water to the

${ }^{7}$ China will finance the construction of several energy projects city, about 8.000 consumers, will help the development of the agriculture in the area, and it is expected to save 1.300 tons of fuel equivalent per year. The construction cost was about 7.000.000 Cuban pesos. The recovery of the investment is expected not to exceed six years. The park has 12.040 solar panels, at about 4.000 solar panels per MW, all produced at the Electronic Component Company "Ernesto Che Guevara," located within the province. National firms also provide the support structures used during the construction of the park.

In 2016, the Cuban electric company in Pinar del Río began the construction of a second solar photovoltaic park with a generating capacity of 2,2 MWp. The facility was constructed in "El Cafetal," in the municipality of San Luis. According to Michel Casals, director of investments in the company, the solar photovoltaic park is providing energy directly to the national electrical grid (Suárez Rivas, 2016).

In addition to the solar photovoltaic parks mentioned above, two new parks have been installed, which will allow to relieve the electric peak of the noon hours and to extend the useful life of the generating units that produce energy in that period of the day. The new sites are set up around Pinar del Rio city, and one of them is backed by a Chinese donation of the technology used during the construction of the solar photovoltaic park. The park has $4 \mathrm{MW}$ of capacity. The Cuban side was responsible for the civil construction and the assembly of the different components of the solar photovoltaic park (Pimentel Miranda, 2017).

According to the government plan, seven photovoltaic solar parks will be built in the province of Pinar del Rio before 2020, to contribute with more clean energy for the electricity generation in the region. Michel Casal Hernández, director of investments of UNE in the western territory, explained that all areas for the construction of the seven solar photovoltaic parks have already been identified. Each of the parks will have a capacity between $5 \mathrm{MW}$ and $10 \mathrm{MW}$.

In total, the eight solar photovoltaic parks that currently have the territory delivered in 2018 to the national electrical grid 22.327 MWh, a figure that exceeds what had been generated previously in the province, since the launch of the first of these facilities in 2015. In 2018, the electricity generated in these eight parks allows a saving of about 5.724 tons of fuel, and stop emitting around 3.720 tons of $\mathrm{CO}_{2}$ into the 


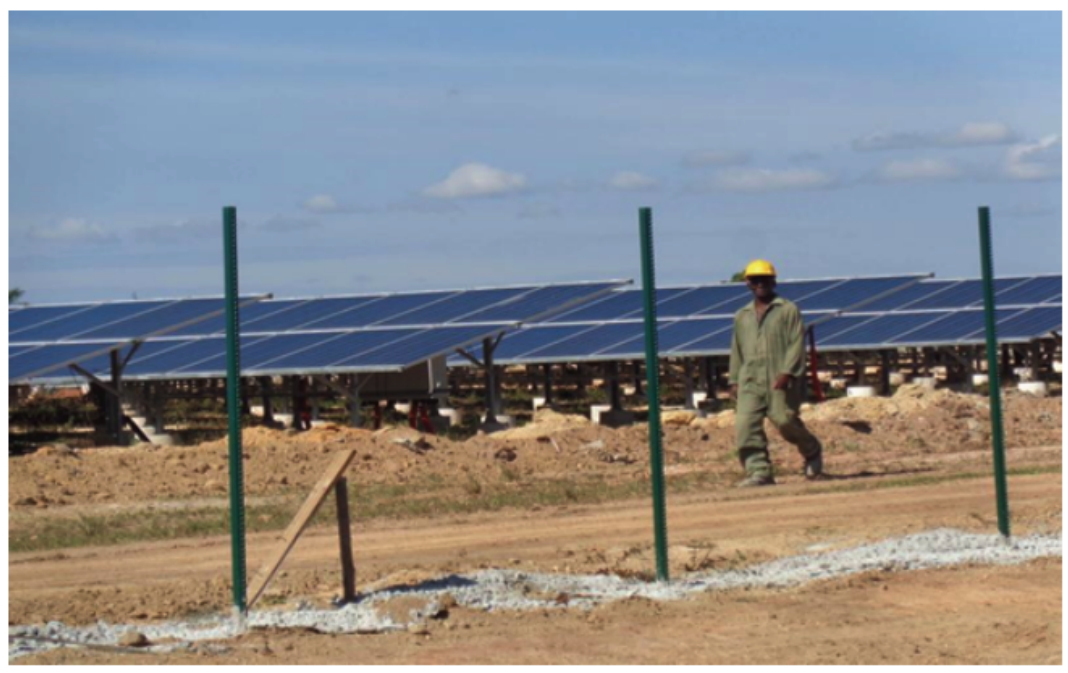

Source: Courtesy of Eduardo Gonzalez.

Figure 5: Solar Photovoltaic Park in Pinar del Rio.

atmosphere, according to the director of renewable energy sources in Pinar del Rio.

Summing up the following can be stated: Pinar del Río has a total of 27 areas prepared for the construction of 11 solar photovoltaic parks before 2030 , which will be implemented through different programs using foreign investment (Corbillon Diaz, 2016). The province is expected to have $99 \mathrm{MW}$ of solar photovoltaic installed capacity by that year (Newsletter FRE, 2016).

\subsubsection{Granma}

The province of Granma, situated in the eastern part of the island, had 1.628 small off-grid solar photovoltaic systems powering medical clinics, local hospitals, schools, social centers, museums, and private homes, located in remote areas without access to the national electrical grid. There are also 426 solar hot-water heaters, three solar distillers to produce water for solar photovoltaic system batteries, and a solar dryer that dries medicinal plants for the Natural Medicine Center located within the province. The Cuban government funded most of these systems and supplied them with solar photovoltaic panels fabricated in Cuba using imported cells.

By 2030, Granma is expected to have nine solar photovoltaic parks, in addition to the photovoltaic park "Yarely 1" already in operation.

\subsubsection{Sancti Spiritus}

In 2019, the province has five solar photovoltaic parks in operation with excellent results. One of these parks operates in the region of Neiva in the municipality of Cabaiguán, another in the area of La Sierpe in the central part of the island, a third one in the municipality of Guasimal, another one in the municipality of Yaguajay, and the last one in the location of Venegas.

The solar photovoltaic park in the municipality of Cabaiguan had a capacity of $4,4 \mathrm{MW}$ and was built in an area of 7,1 ha. It is expected that this solar photovoltaic park will generate $6.600 \mathrm{MW} / \mathrm{h}$ per year, when connecting to the national electrical grid, and will save the consumption of 1.700 tons of oil per year.

The solar photovoltaic park constructed in the municipality of Guasimal had an installed capacity of 4,4 MW and was built at the cost of 12 million Cuban pesos or US $\$ 480.000$. The construction of the park was financed by China.

The solar photovoltaic park built in the municipality of Sierpe has 525 solar panels module (10 solar panels each), and it is expected to supply $2.000 \mathrm{MWh}$ to the national electrical grid. The construction cost of the park was 3 million Cuban pesos and was built on 2,5 ha.

The solar photovoltaic park built in Neiva began operation in January 2019. The park has an installed capacity of $2,2 \mathrm{MW}$, has a total of 8.000 solar panels with 400 tables, and its construction cost was 7,8 million Cuban pesos or US\$312.000. It is expected that in one year this solar photovoltaic park will generate 3.300 MWh. The technology used was provided by China. 
The solar photovoltaic park in the location of Venegas has an installed capacity of $1,25 \mathrm{MW}$, and it is expected to provide around $1.875 \mathrm{MWh}$ to the national electrical grid. The Abu Dhabi Fund financed the construction of the park in cooperation with the European Union.

The purpose of the government is to build in Sancti Spiritus in the coming years at least 14 solar photovoltaic parks, which will distinguish the province as the region where the highest number of solar photovoltaic parks will be constructed. The government plan is to have, at the end of 2019 , solar photovoltaic parks in operation to satisfy around $70 \%$ of the total electric demand of the province at lunchtime.

The new solar photovoltaic parks to be constructed in the province will be conditioned with modern technology, either by driving or percussion of metal beams, so the field tests have been decisive in determining the ideal site for the construction of these parks.

\subsubsection{Guantánamo}

In December 2013, the "Santa Teresa-Los Güiros" solar photovoltaic park in Guantánamo, with 10.800 solar panels built on 5 ha started to generate electricity to the national electrical grid.

\subsubsection{Mariel Special Development Zone}

Cuba will install three photovoltaic parks with foreign capital in the Mariel Special Development Zone. The solar photovoltaic park will have a capacity of 50 $\mathrm{MW}$, is expected to generate $102 \mathrm{GW} / \mathrm{h}$ per year, and will have more than 300.000 solar panels distributed in three locations, according to the president of the company Mariel Solar S.A., Bernardo Fernández, quoted by the state news agency Prensa Latina.
The project was awarded, in 2016, to the British company Hive Energy, after a negotiation process that included electricity sales contract to the Cuban counterpart. Using the national standard of US\$2 million per $\mathrm{MW}$, the total cost of the construction of these three parks is estimated at US $\$ 100$ million. The construction of these three solar photovoltaic parks is expected to be concluded before the end of 2020 .

\subsubsection{Holguin}

The province will have, in 2030 , a total of 23 solar photovoltaic parks with a total capacity slightly above $90 \mathrm{MW}$

\subsection{Electricity Generation by Solar Energy}

If the government wants to reach its goal of $24 \%$ of electricity generation using renewable energy sources by 2030 , then it needs to add at least $633 \mathrm{MW}$ of wind capacity, $700 \mathrm{MW}$ of solar photovoltaic, and $860 \mathrm{MW}$ of biomass to its current energy mix. While several of the projects to install new renewable capacity will be $100 \%$ Cuban owned, the government is looking for foreign investment to implement over 200 of these renewable energy projects (Morales Pedraza, 2018). In the case of projects in the field of solar energy, the government has plans to receive US\$700 million of foreign resources to build several solar photovoltaic with a total capacity of $350 \mathrm{MW}$

Finally, it is essential to state the following: the government has plans to reach, by the end of 2019 , over $17 \%$ of the solar photovoltaic energy plan until 2030 already implemented.

\subsection{Looking Forward}

The MEM will carry out pre-feasibility studies to install 1.666 .000 solar panels during the coming years.

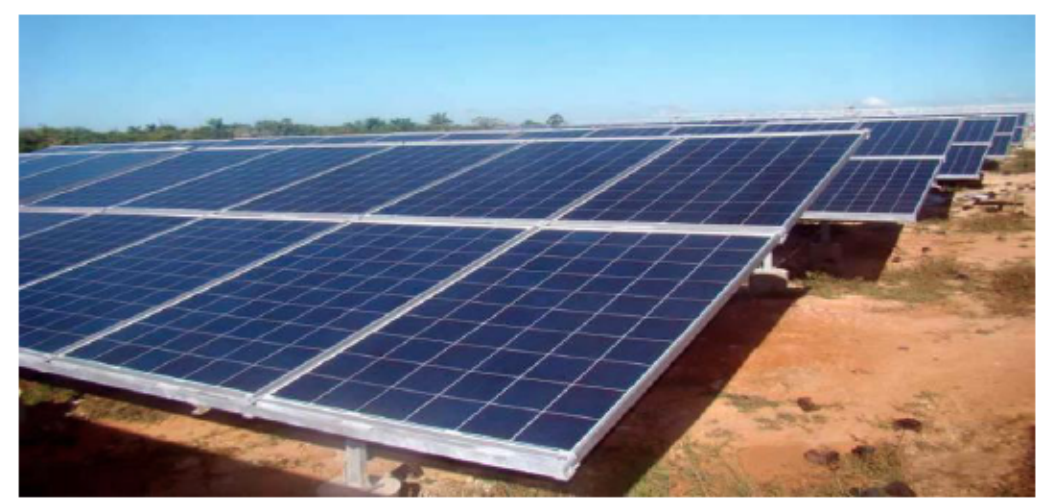

Source: Courtesy of Ronald Suárez

Figure 6: Solar photovoltaic panels. 
The aim is to generate $490 \mathrm{GW} / \mathrm{h}$ per year, at an estimated operating cost of $0.002 \mathrm{CUC}^{8} / \mathrm{kWh}$ in several provinces of the island. This program will replace the consumption of 122.470 tons per year of fossil fuel (mainly oil). The investment is expected to be recovered in 11 years.

To ensure the implementation of the program mentioned above, the government will increase the capacity of the national company "Ernesto Che Guevara" of Pinar del Rio to up to $50 \mathrm{MWp}$. The aim is of satisfying the needs of solar panels for the construction of several solar photovoltaic parks to be installed throughout the country before 2030. On the other hand, the national industry is expected to produce components and aggregates for the solar photovoltaic parks to be built during the coming years, such as the inverter, panel mounts (tables), transformers, blackboards, electrical cables, and hardware.

The program will use completely the factory design capacity of vacuum tube heaters "RENSOL" $(50,000$ units) located in Morón, Ciego de Ávila in the central region of the island. The factory will also manufacture solar dryers for food, seeds, wood, and medicinal plants of assorted designs. It will also develop the production of solar concentrators to generate electricity.

Finally, it is important to highlight, according to recent government public sources, that the Cuban government intends to expand the use of solar photovoltaic systems in the future by increasing the capacity to be built by 2030 from $700 \mathrm{MW}$ to 1.000 MW.

\section{CONCLUSION}

Cuba is increasing its renewable energy capacity already installed for electricity generation with the aim of reducing the participation of oil in the energy mix of the country by 2030 . Solar energy will be one of the renewable energy sources that will increase its involvement in the energy mix of the country by 2030 . The program approved by the government foresees the construction of 191 solar photovoltaic parks with national and foreign resources with a total capacity of $700 \mathrm{MW}$ by 2030 . The above-mentioned solar energy

\footnotetext{
${ }^{8} \mathrm{CUC}$, the convertible Cuban pesos, has a rate of exchange $1 \mathrm{CUC}=0.89$ US dollars (included 10\% penalty for the use of US dollars in the transaction).
}

capacity will represent $3 \%$ of the full capacity to be installed in the country by 2030 .

The country is carrying out an Energetic Revolution with the aim of reducing the use of fossil fuels for electricity generation and increase, in the same proportion, the use of different renewable energy sources for this specific purpose.

It is important to single out that the energy transition in Cuba began several years ago, but without having a comprehensive policy, nor a regulatory framework for the use of new energy sources. No specific projects were identified for the increased use of renewable energy sources for electricity generation, and together with the lack of financial and human resources needed to implement this program, among other factors, limited the speed that the program was performed at the beginning.

There was also an absence of awareness about the need to use this type of energy source for electricity generation, not only at the decision-makers level but within the society as well. It must be recognized that, despite the efforts of some institutions and research centers related to the subject, there was no real understanding of the need for these changes within the government (Morales Pedraza, 2018).

However, in 2006, the government began to take firm steps with the declaration of the "Energetic Revolution" in Cuba. The purpose of this program is to change the energy mix of the country by increasing the use of all available renewable energy sources in the country (see Figure 7).

The shift towards an economy not based on fossil fuels inevitably leads to an increase in the use of renewable energy sources. Thanks to the development of the technologies associated to the different renewable energy sources over the last twenty years, the actual costs of generating wind and solar electricity have been reduced to about US $\$ 0,10$ per $\mathrm{kW} / \mathrm{h}$ or less. This cost is significantly lower than the cost of the electricity generated by the power plants that burn oil within the country, which is around US $\$ 0,20$ per $\mathrm{kW} / \mathrm{h}$. The same applies to biomass and hydropower.

The government is expecting that, by 2030, the energy mix of the country will be the following (see Figure 7): 


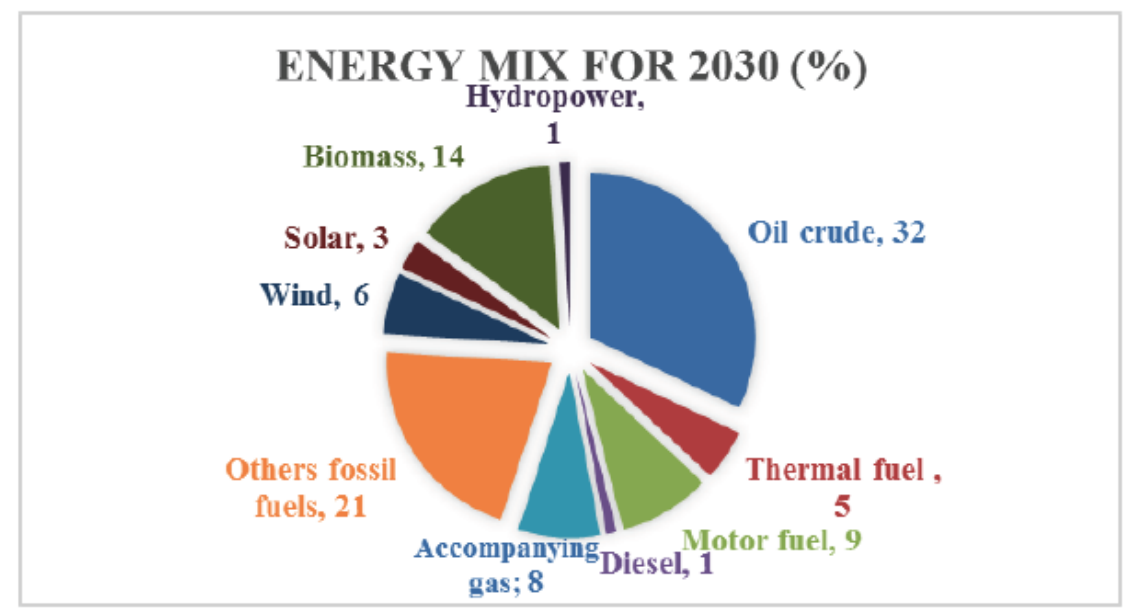

Source: Julio C. Ramada, IMRE

Figure 7: Energy mix for 2030.

- $\quad$ Fossil fuels: $32 \%$;

- $\quad$ Other fossil fuels: $21 \%$;

- $\quad$ Biomass: $14 \%$;

- Wind energy: 6\%;

- $\quad$ Solar energy: 3\%.

With the aim of saving resources as much as possible, as well as the reduction in the use of fossil fuels for electricity generation and the emission of $\mathrm{CO}_{2}$ to the atmosphere, the government will increase the use of renewable energy sources for electricity generation within the energy mix of the country up to $24 \%$ by 2030 . However, and according to Figure 7 , the use of fossil fuels for electricity generation will continue to be, in 2030, the primary energy sources used in Cuba for this purpose (76\%) with a negative impact on its economy.

The total capacity by type of renewable energy source to be installed in Cuba by 2030 is shown in Table 5

Table 5: Capacity to be Installed by 2030 by Energy Source

\begin{tabular}{|c|c|}
\hline Energy Source & Capacity to be Installed (MW) \\
\hline \hline Biomass & 860 \\
\hline Wind & 633 \\
\hline Solar Photovoltaic & 700 \\
\hline Hydropower & 56 \\
\hline Biogas & 27 \\
\hline
\end{tabular}

Source: Moreno Figueredo.

\section{REFERENCES}

[1] C. Ramada, Julio (2016), Energies' Renovables en Cuba [Renowable energies in Cuba], IMRE, U.H., 2016.

[2] Cuba: A country profile on sustainable energy development (2008); jointly sponsored by the International Atomic Energy Agency, Centro de Gestión de la Información y Desarrollo de la Energía and the United Nations Department of Economic and Social Affairs; International Atomic Energy Agency; Vienna, Austria; 2008.

[3] Energy Information Administration, U.S. database, 2016.

[4] Energy Information Administration, US database, 2018.

[5] Energy Information Administration, US database, 2019.

[6] Energy Landscape for Latin America and the Caribbean (2018); OLADE; 2018.

[7] Figueredo Reinaldo, Oscar; Garaycoa Martínez, Roberto; and Domínguez, L Eduardo (2017), Cuba avanza en el uso de energías renovables [Cuba advances in the use of renewable energies], published in: Actualización del modelo socialista cubano [Üpdate of the Cuban socialist model], 22 February 2017.

[8] Guevara-Stone, Laurie (2009); La Revolución Energética [The Energy Revolution]: Cuba's Energy Revolution. Renewable Energy World Magazine. 9 April 2009.

[9] International Renewable Energy Agency (IRENA), Installed Capacity Trends, 2019.

[10] La Razón Digital, La Habana, Cuba empleará por primera vez energía de las olas para mover agua estancada [Digital Reason, Havana, Cuba will use for the first time wave energy to move stagnant water], EFE, septiembre 2016.

[11] Morales Pedraza, Jorge (2013); Energy in Latin American and the Caribbean: The Current and Future Role of Renewable and Nuclear Energy Sources in the Regional Electricity Generation; ISBN: 978-1-62257-980-8; Nova Science Publisher Inc.; 2013.

[12] Morales Pedraza, Jorge (2018); Renewable Energy Sources in Cuba: Current Situation and Development Prospects; Chapter 2 of the book entitled "Focus on Renewable Energy Sources"; ISBN 9781536138023; Nova Science Publishers; 2018.

[13] Moreno Figueredo, Conrado, Cuba hacia 100\% energías renovables, Transición energética en Cuba [Cuba towards $100 \%$ renewable energy, Energy transition in Cuba], Cubasolar, www.cubasolar.cu. 
[14] National Energy Sources Development Program; Cuba.

[15] Newsletter FRE, Knowledge Management Group, Technical Direction. National Electrical Union, number 37, September 2016.

[16] Pimentel Miranda, Zorileidys (2017), Work in Pinar del Rio in installation of new photovoltaic parks, Radio Guamá, Cuba, 2017.

[17] Rodriguez, Andrea (2012); Cuba's Renewable Energy: Gov. Missing Out On Solar, Wind Power Opportunities, Experts Say. Huffington Post 7.5.2012, http://www.huffingtonpost.com/2012/07/05/cuba-renewableenergy-alternative-solar wind_n_1651216.html, 2012.

[18] Rodriguez, Andreas (2013), Cuba's first solar farm a step toward renewable, 2013.

[19] Seifried, Dieter (2013); Cuban Energy Revolution - A Model for Climate Protection? Freiburg: Büro Ö-quadrat. http://www.oe2.de/fileadmin/
user_upload/download/Energierevolution_Cuba_eng.pdf, $201 \overline{3}$.

[20] Slade, Giles (2006); Made to Break: Technology and Obsolescence in America. Harvard University Press. 330 pp; 2006.

[21] Suárez, José Antonio; Aníbal Beatón, Pedro; Faxas Escalona, Rodolny; and Pérez Montero, Ofelia (2012); Energy, environment and development in Cuba, Renewable and Sustainable Energy Reviews, journal home page: www.elsevier.com/locate/rser, 2012.

[22] Suárez Rivas, Ronald (2016); Pinar del Río committed to the use of solar energy, Granma, 2016.

[23] Valdés, Magdalena (2017); Cuba incorporará 59 parques fotovoltaicos a la generación eléctrica, Granma, [Cuba will incorporate 59 photovoltaic parks to electricity generation, Granma,] January 2017.

Received on 20-3-2019

Accepted on 28-3-2019

Published on 28-3-2019

DOI: http://dx.doi.org/10.31875/2410-2199.2019.06.1

(C) 2019 Jorge Morales Pedraza; Zeal Press.

This is an open access article licensed under the terms of the Creative Commons Attribution Non-Commercial License (http://creativecommons.org/licenses/by-nc/3.0/), which permits unrestricted, non-commercial use, distribution and reproduction in any medium, provided the work is properly cited. 